\title{
Effect of Financial Leverage on the Trend of Stock Pricing Fluctuations in Companies Listed in Tehran Stock Exchange
}

\section{Efecto del apalancamiento financiero en la tendencia de las fluctuaciones en el precio de las acciones en las empresas que cotizan en la Bolsa de Teherán}

\author{
Goran Karimi \\ Islamic Azad University of Mahabad, Iran \\ ORCID: https://orcid.org/0000-0002-5769-8521
}

Received 02-12-20 Revised 02-25-20 Accepted 06-13-20 On line 06-29-20

*Correspondence

Email: Erofeeva-ma72@yandex.ru
Cite as:

Karimi, G. (2020). Effect of Financial Leverage on the Trend of Stock Pricing Fluctuations in Companies Listed in Tehran Stock Exchange. Propósitos y Representaciones, 8 (SPE2), e654. Doi: http://dx.doi.org/10.20511/pyr2020.v8nSPE2.654

(c) Universidad San Ignacio de Loyola, Vicerrectorado de Investigación, 2020. 
The key factor in creating value in companies and banks is the capital structure and financing method so that companies are moving towards creating value through debt control and the use of proper financing. Therefore, the present study was conducted to investigate the effect of financial leverage on the stock price volatility trend in listed companies in Tehran Stock Exchange for the period 2011-2018 using systematic elimination method. The results of data analysis showed that financial leverage capital has significant effect on the trend of stock price volatility in listed companies in Tehran Stock Exchange.

Keywords: Financial Leverage; Fluctuation; Price.

\section{Resumen}

El factor clave para crear valor en las empresas y los bancos es la estructura de capital y el método de financiación para que las empresas se muevan hacia la creación de valor a través del control de la deuda y el uso de una financiación adecuada. Por lo tanto, el presente estudio se realizó para investigar el efecto del apalancamiento financiero en la tendencia de volatilidad del precio de las acciones en las compañías que cotizan en la Bolsa de Teherán para el período 2011-2018 utilizando el método de eliminación sistemática. Los resultados del análisis de datos mostraron que el capital de apalancamiento financiero tiene un efecto significativo en la tendencia de la volatilidad del precio de las acciones en las compañías que cotizan en la Bolsa de Teherán.

Palabras clave: Apalancamiento financiero; Fluctuación; Precio.

\section{Introduction}

The effect of financial leverage on corporate investment decisions is one of the key issues in financial management. According to Miller and Modigliani's theory, investment decisions are independent of the financing process. The theory argues that the cost of capital is irreversible irrespective of the amount of leverage. As long as companies have profitable investment opportunities, they can find sources to finance them, regardless of their balance sheet. Managers, on the other hand, do not show much interest in financing investments through debts, as creditors also share in the outflow of investment. Thus, as the debt of the shareholder-manager coalition increases, it reduces opportunities for investing in positive net present value. By reducing the value of the company with high leverage companies may face liquidity problems in financing for projects with positive net present value. This affects the ability to participate in financing growth opportunities. Under these conditions, a high leverage can make the underinvestment problem. Therefore, companies with high leverage will be less able to take advantage of growth opportunities (Franklin et al., 2011). One of the effective factors in identifying the financial ability of companies is financial leverage. Financial leverage has the potential to increase financial distress. Various studies have evaluated the effect of financial leverage on firm performance negative, indicating that firm leverage increases their risk (for example, Hsu and Jang, (2008), Koh et al. (2009), Park and Lee (2009), Tsai and Gu (2007)). The first and most important factor affecting investor decision making in the stock market is the stock price index. Therefore, awareness of the factors affecting the stock price is important. Naturally, there are many factors that affect the formation of information and perspectives of market parties and ultimately the price of corporate stock. Some of these factors are internal and some are due to the situation of variables outside the scope of the domestic economy (Chaibi et al., 2013). Given the importance of pricing fluctuations and corporate capital structure, the purpose of the present study is to investigate the effect of financial leverage on the trend of stock pricing fluctuations in companies listed in Tehran Stock Exchange. 


\section{Theoretical Foundations and Literature}

A company's capital structure describes the company's financing activities using a combination of debt and equity to optimize the company's value (Oino and Ukaegbu, 2015). Choosing the right capital structure and different financing methods is a major concern for financial managers of companies. Inadequate capital structure in any company affects different areas of the company's activity and can lead to issues such as inefficiency in product marketing, inefficiency and inability to properly employ human resources and so forth. The optimal capital structure will be achieved when the market value of each share is maximized. In order to determine the optimal capital structure, the use of earnings per share, break-even point, and degree of financial leverage as acceptable methods of measuring risk and return is necessary. Determining the optimal capital structure under real conditions is a difficult task and goes beyond purely theoretical discussions (Nikoomaram et al., 2009). A company's capital structure illustrates the relationship between debt and equity. The capital structure of a company that has no debt consists of equity, and since the capital structure of most companies is a capital structure with debt and equity, and the sources of debt increase leverage and, as a result, the company risk while increasing fixed costs, financial managers are very sensitive and careful about the getting loans and its effects. Various events may drive companies away from their target capital structure. If the costs of adjusting capital structure are high, reaching the target levels may be costly and consequently the company will not adjust it despite being aware of the optimal capital structure. This may indicate that it is more useful to study financial decisions in a dynamic context. It is important to note that companies are often faced with a budget surplus / deficit and these conditions provide a good framework for adjusting the capital structure with low transaction costs (Obreja, 2013). If equity transaction costs are higher than debt, companies with surplus debt are more likely to have debt rather than equity, companies with surplus debt are more likely to reduce debt rather than equity to leave a debt reserve for future financing needs and avoid more costs of re-issuing equity. Therefore, adjustments to a time target can be asymmetric so that companies weigh the positive and negative deviation of the target debt ratio differently. In addition, this asymmetry in the speed of adjustment is expected to be conditional on the existence of a financial surplus or deficit (Dulo et al., 2016). Different levels of leverage are commonly used to calculate stock costs. Over the years, the relationship between stock returns and leverage has been examined and yielded different results. In some cases, stock returns do not appear to be related to leverage. In other cases, leverage is significantly and negatively related to stock returns (Phillipo et al., 2017). The effect of financial leverage on company value is one of the most challenging and controversial issues of financial management. Managers try to maximize the company value by choosing the right mix of different financing sources. Debt is one of the most important sources of financing for companies, and increase in debt is one way to achieve this. Due to the low cost of debt, companies that use debt to finance part of their financial sources are expected to have higher value than companies whose entire capital is funded by shareholders (Ozdagli, 2012). In order to develop the stock market as an organized entity of the capital market, the behavior of stock prices therein is important for stock buyers, brokers, stock managers and the government. Therefore, there is an urgent need to understand the underlying factors explaining the price of these assets. Financial theories state that the value of a share is equal to the present value of its expected earnings. The tendency to understand stock pricing in the absence of a uniform set of variables that represents the expected future results will lead to the rapid emergence of stock pricing models while virtually all stock pricing models and frameworks are based on one theoretical foundation (Xu et al., 2012). The capital required for different investment projects of a company is provided by different groups of investors who have different claims about the expected future earnings of the company. These required funds of the company may be provided by the accumulated profits of the company, the sale of new shares, debts (debt facilities and bonds) or by a combination of these resources. The lenders are entitled to receive interest with fixed rates and have priority over other obligations of the company. After paying interest and tax expense and dividends to the preferred shareholders, 
the remaining profits are owned by the ordinary shareholders (Atkeson, 2005). Factors affecting stock prices can be classified into internal and external factors: Internal factors include factors affecting the stock price in relation to the company's operations and decisions. These include earnings per share (EPS), dividend per share (DPS) and price-to-earnings ratio, increase in stock split capital and other factors inside the company. External factors include factors that are out of the authority of the company's management that affect the company's performance in some way (Fetros et al., 2017).

\section{Mutual relationship between financial leverage and dividend}

According to the hierarchy theory, companies finance projects with accumulated profits. If a company pays significant sums for dividends, the amount of free cash flow will decrease. As a result, the need for extra-organizational resources to maintain the optimal capital structure increases (DeAngelo et al., 2006). According to this theory, there is a positive relationship between debt and dividends, because high dividend payments reduce the level of free cash flow (intra-organizational resources). As a result, the need for debt financing to maintain the desired structure increases. The role of dividends in a flawed information environment is to disseminate private information to the market. Debt creation (mainly financing through current debt) may be an awareness tool (Aggarwal et al., 2010).

According to the leverage effect theory, changes in stock returns have a negative effect on volatility. Therefore, decreasing returns on the stock market increases volatility in this market. This effect shows that changes in the firm's capital structure, or in other words, the change in the debt-to-asset ratio (leverage ratio), affect the rate of the firm's stock fluctuations. Black showed that the change in value resulting from the decline in the firm's stock price, while reducing the value of its assets, had little effect on the value of its debt. In other words, firm debt has much less volatility (risks) than changes in assets (price or return). As a result, changing the firm value changes the value of firm's assets and stocks. Therefore, the ratio of leverage and volatility of firm returns will change (Dong, 2015).

Hong et al. (2019) investigated the impact of financial leverage on pricing fluctuations in a study. The sampling method in this study is systematic elimination. The results show the accuracy of leverage random instability models in pricing options when leverage is high. In addition, as maturity of the options increases, the leverage effect increases. In addition, leverage affects the pricing of options inside the currency more than options in the currency and out of the currency.

Saati Ghare Musa et al. (2017) in a study examined the relationship between financial leverage and market size and stock returns of listed companies in Tehran Stock Exchange. The main purpose of this research is to investigate the relationship between financial leverage changes and stock returns and market size and stock returns. This research was conducted on listed companies in Tehran Stock Exchange over a period of eight years from 2006 to 2013 and is a sample of 5 companies. The data were collected using financial statements, board reports and annual audit reports as well as reports prepared by the Stock Exchange, after extracting the data from the Rahavard Novin Database and performing preliminary calculations related to variables and initial data processing using Excel software, the research hypotheses were tested using SPSS software. The results show that there is a direct relationship between financial leverage and stock returns and between market size and stock returns.

In a study, Aghajan et al. (2016) investigated the impact of financial structure on stock price fluctuations of listed companies in Tehran Stock Exchange. The present study examines the relationship between financial structure and stock price fluctuations in the listed companies in Tehran Stock Exchange during the years 2010 to 2014. To investigate the research hypotheses, panel data regression method and EViews software were used. The results showed that there is a negative significant relationship between short-term bank borrowing and capital increase and 
stock price fluctuations, but there is no significant relationship between long-term bank borrowing and stock price fluctuations.

Ansari et al. (2012), in a study entitled "examining the impact of operating leverage and financial leverage on capital cost", states that the present study examines the impact of operating leverage and financial leverage on capital cost in Tehran Stock Exchange. The statistical method used to investigate the hypotheses is to calculate the correlation coefficient between the research variables and also to test the relevant hypothesis for the effect of the independent variable on the dependent variable. The results of this study showed that in Tehran Stock Exchange, the relationship between capital cost and operating leverage and financial leverage varies from one industry to another. In other words, the relationship between capital cost and operating leverage and financial leverage is positive in one industry, positive and significant in another, negative in another, and negative and significant in another.

\section{Method}

The present study is a correlation analysis in terms of research approach. On the other hand, this study has a quantitative approach. As in this method, the data are quantitative in nature and the conclusion of them requires statistical calculations and have been analyzed using software. On the other hand, this research is applied in terms of purpose and is a descriptive-correlational research in terms of data collection method. Descriptive research involves a set of methods that are intended to describe the conditions or phenomena under study. Among the descriptive researches, as in the present research, independent and dependent variables have occurred in the past, it is a post-event research. In post-event research, the researcher seeks to explore the relationships between factors and specific conditions that already existed or occurred through the study of their results. Their previous context is hoping to find the cause of the phenomenon or action. Therefore, the researcher seeks to investigate the possibility of causal relationships by observing and studying the existing results and their previous context in the hope of finding the cause of the phenomenon or action. As a result, the researcher does not interfere with the data. The statistical population in this study are companies listed in Tehran Stock Exchange during 2011-2018. The reason for the selection of the Stock Exchange as the statistical population is that the Stock Exchange includes all companies that are active in different industries. On the other hand, according to the purpose of the research, the Stock Exchange is considered as the statistical population.

$$
y=\beta_{0}+\beta_{1} x_{1}+\varepsilon
$$

$\boldsymbol{y}:$ Stock price fluctuation

$x_{1}$ :Financial leverage obtained by dividing the debt-to-equity ratio (Lee et al., 2011). follows:

According to the purpose of the research, the hypothesis of the present research is as

Financial leverage has a significant effect on the trend of stock price fluctuations in companies listed in Tehran Stock Exchange.

Descriptive achievements in the present study are discussed in this section. Each of these indices is then examined for each of the variables included in this study. 
Table 1.

Descriptive statistics of the research variables

\begin{tabular}{cccccccc}
\hline Variable & Mean & Median & $\begin{array}{c}\text { Standard } \\
\text { deviation }\end{array}$ & Maximum & Minimum & Skewness & Kurtosis \\
\hline $\begin{array}{c}\text { Price } \\
\text { fluctuations }\end{array}$ & 0.557748 & 0.570365 & 0.183001 & 0.851589 & 0.238331 & -0.110127 & 1.732749 \\
$\begin{array}{c}\text { Financial } \\
\text { leverage }\end{array}$ & 0.761535 & 0.763028 & 0.131632 & 0.991655 & 0.530912 & -0.061590 & 1.796046 \\
\hline
\end{tabular}

Table 1 represents the descriptive information of the research variables. The mean price fluctuation is 0.557748 . This value indicates that most companies have price fluctuation close to this number. The median of this variable is 0.570365 . This value indicates that half of the population has price fluctuation less than this value and half of them more than this value at the company level. The maximum and minimum numbers for this variable are 0.851589 and 0.223331 , respectively. The standard deviation number is 0.183001 which indicates the deviation of the price fluctuation at the company level (with respect to the minimum and maximum values) among the statistical population. The mean financial leverage is 0.761535 . This value indicates that most companies have financial leverage close to this number. The median of this variable is 0.763028 . This value indicates that half of the population has financial leverage less than this value and half of them more than this value at the company level. The maximum and minimum numbers for this variable are 0.991655 and 0.560912 , respectively. The standard deviation number is 0.131632 which indicates the deviation of the price fluctuation at the company level (with respect to the minimum and maximum values) among the statistical population.

The White test with two criteria of Fisher exact test and chi-square test was used to assess the establishment of presumption of homogeneity, consistency, or stability of the variances. In this test, the null hypothesis of homogeneity of variances versus their heterogeneity is defined as the contrary hypothesis. The results of the variance homogeneity test are summarized in Table 2.

Table 2.

Variance homogeneity test

\begin{tabular}{|c|c|c|c|}
\hline Type of test & Test statistic & Sig. level & Test result \\
\hline Fisher & 4.36563 & 0.0000 & $\begin{array}{l}\text { Acceptance of the assumption of } \\
\text { homogeneity of variances }\end{array}$ \\
\hline Chi-square & 6.36563 & 0.0000 & $\begin{array}{l}\text { Acceptance of the assumption of } \\
\text { homogeneity of variances }\end{array}$ \\
\hline
\end{tabular}

Based on the results summarized in Table 2 on the White test, it can be seen that:

1.The Fisher test statistic was 4.36563 and its corresponding test level was approximately zero.

2.The chi-square test statistic was 6.36563 and the corresponding significance level was approximately zero.

3.

Given that the test level in both Fisher and Chi-square tests was less than 5\%. Therefore, at the $95 \%$ level of confidence, the null hypothesis on stability, homogeneity, or equality of variances can be accepted as another presumption of using compound linear regression to determine the relationship between variables. 


\section{Investigating stationarity of the research variables}

Before estimating the model, it is necessary to examine the stationarity of its variables. A variable is stationary when its mean, variance, and covariance remain constant over time. In general, if the temporal origin of a variable changes and the mean, variance, and covariance do not change, then the variable will be non-stationary.

The hypotheses about stationarity of the variables are as follows:

$\left\{\begin{array}{l}\mathrm{H}_{0}: \text { Variable is non-stationary. } \\ \mathrm{H}_{1}: \text { Variable is stationary. }\end{array}\right.$

The stationarity of the variables can be studied in three modes: "on the level", "at the first difference" and "on the second difference". Variables whose probability of testing them "at the level" is less than 5\%, the null hypothesis about it is rejected and that variable is at the stationary level, if it is more than 5\%, it is non-stationary. The results of the stationarity test are listed in Table 3-4.

Table 3.

Evaluating the stationarity of the research variables

\begin{tabular}{ccc}
\hline Variables & Levin Lin Chu statistic & Sig. level \\
\hline Price fluctuation & -15.5381 & 0.000 \\
Financial leverage & -12.2161 & 0.000 \\
\hline
\end{tabular}

According to the results in Table 3, the test statistic level is less than 5\%. Therefore, considering that the significance level is less than 0.05 , the research variables have the required stationarity.

Hypothesis: Financial leverage has a significant effect on the trend of stock pricing fluctuations in companies listed in Tehran Stock Exchange.

Since the present research data are panel data, in this type of data, the F-Limer test was used to select between panel data and combined data. The results of this test are summarized in Table 4.

Table 4.

Results of the F-Limer test

\begin{tabular}{ccc}
\hline F statistic & Sig. value & Test result \\
\hline $\mathbf{1 . 0 2 1 8 6 9}$ & 0.4378 & \\
\hline
\end{tabular}

Given the significance value which is less than 0.05 , the panel data method is therefore accepted.

Table 5.

Analysis results

\begin{tabular}{ccccc}
\hline Variable & Coefficient & Standard deviation & t statistic & Sig. level \\
\hline Financial leverage & 0.138762 & 0.043102 & 2.985623 & 0.0390 \\
Constant coefficient & 0.018352 & 0.015708 & 1.996365 & 0.0432 \\
Coefficient of determination & 0.4049241 & f statistic & 6.479419 \\
Adjusted coefficient of determination & 0.391003 & Sig. level & 0.003566
\end{tabular}

Durbin-Watson: 2.050011 
The significance level for testing this hypothesis for financial leverage is 0.0390 and since the significance level is less than 0.05 , so the null hypothesis is rejected at $95 \%$ confidence level. This means that financial leverage has a significant effect on the trend of stock pricing fluctuations in companies listed in Tehran Stock Exchange. Given the calculated values of $t$ and in the last column of the values, the probability level is low. Therefore, both coefficients are significantly different from zero. In other words, the $\mathrm{T}$ statistic is equal to 2.985623. The coefficient of determination (R2) is 0.4049241 , which means that the change in the financial leverage has been able to explain 40.49 units of price fluctuation changes in the company. The value of $F$ statistic indicates the overall significance of the regression and, in other words, the effect of the significance of the variable, which is 6.479419 , which is needed to show the power of the regression equation in the prediction, the Watson-Durbin statistic used to identify the independence of errors shows the value of 2.050011 which indicates that there is no autocorrelation between the error components. According to the results of the analysis, it can be said that the research hypothesis is confirmed. In other words, financial leverage has a significant effect on the trend of stock pricing fluctuations in companies listed in Tehran Stock Exchange.

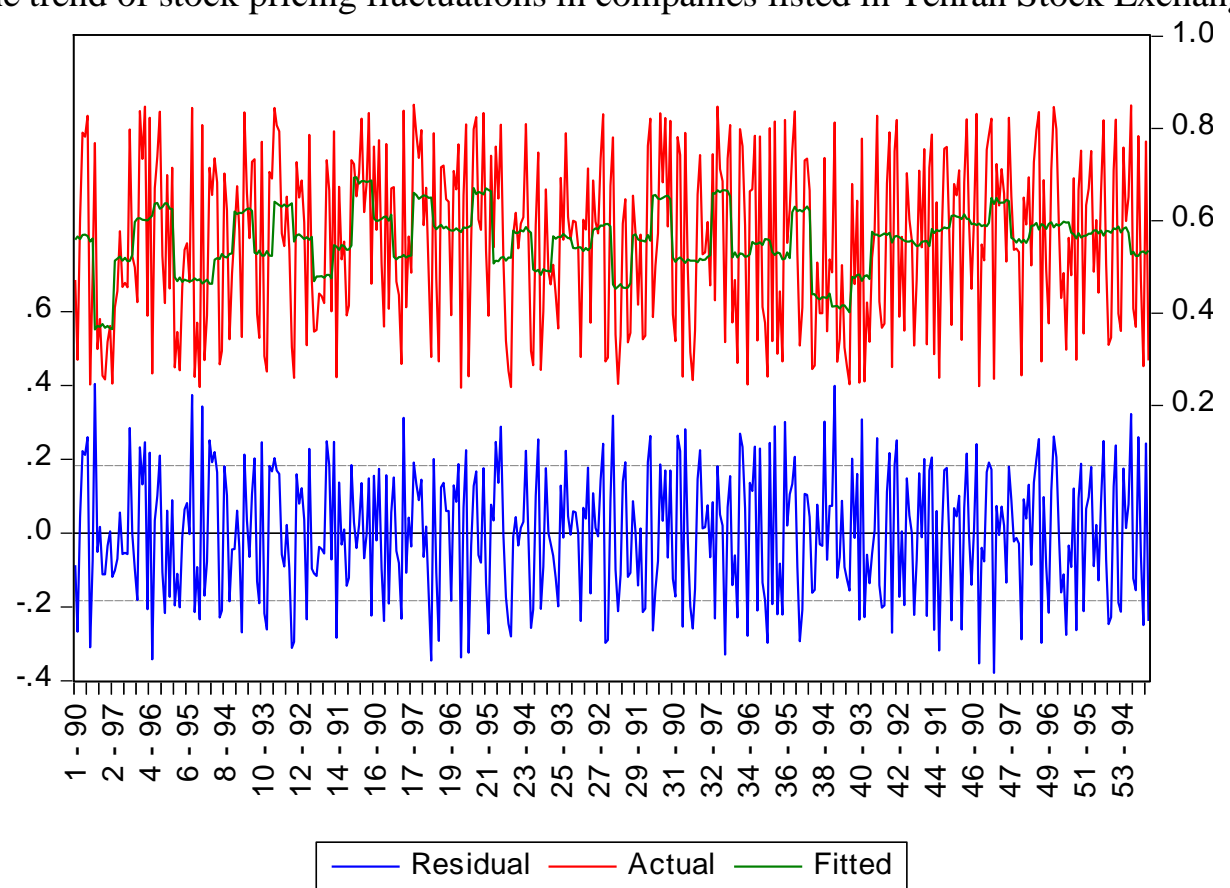

Figure 1. Trend of regression variation in the research hypothesis

\section{Conclusion}

The purpose of this study was to investigate the effect of financial leverage on the trend of stock pricing fluctuations in companies listed in Tehran Stock Exchange. The results showed that the research hypothesis, financial leverage has a significant effect on the trend of stock price fluctuations in companies listed in Tehran Stock Exchange, is confirmed due to having a significance level less than 0.05 . Therefore, it can be said that financial leverage has a significant effect on the trend of stock price fluctuations in companies listed in Tehran Stock Exchange. In other words, if the financial leverage changes and fluctuates, the price is overshadowed. The results of the research are consistent with studies by Hong et al. (2019), Hong et al. (2019), Saati et al. (2017).

\section{Research limitations}

Taking a step to achieve a goal is always accompanied by limitations that make it difficult to achieve the desired goal. Research as a process to achieve the goal of solving the research problem is no exception. In this regard, the limitations of the present research are as follows: 
A. The present research was conducted using the data of companies listed in Tehran Stock Exchange and other companies were excluded from the statistical population due to the specific nature of their activity, therefore, the results cannot be generalized to all companies.

B. In the economic and accounting models, the analysis of future behavior of companies is based on their past behavior. Whereas in uncertain and volatile conditions the results of the research may not be valuable or inconsistent with reality. In fact, predicting the future based on past results is reliable if we have stability and confidence.

C. Another limitation of the research is the error of data collection by the researcher which may be somewhat effective in generating wild and influential observations

\section{Suggestions}

In this section, based on the results and findings of the study, two categories of suggestions are proposed. First, practical suggestions that are hoped to help users of accounting and financial information, particularly investors and managers, make decisions, and second, suggestions for future research that can guide future research on the topic of research.

\section{Practical suggestions}

$\checkmark \quad$ It is recommended to use profitable capital structures with the least loss to improve the performance of listed companies in stock exchange.

$\checkmark \quad$ It is suggested that appropriate financing practices be used to improve the conditions of listed companies in stock exchange.

$\checkmark \quad$ It is suggested that future research on factors affecting stock price fluctuation be examined.

$\checkmark \quad$ It is suggested to consider appropriate solutions to prevent stock price fluctuations.

\section{References}

Aggarwal, R. and N. A. Kyaw (2010). Capital Structure, Dividend Policy, and Multinationality: Theory Versus Empirical Evidence", International Review of Financial Analysis, Vol. 19, No. 2, pp. 140-150

Aghajan, Z, \& Ohadi, F (2015). The Impact of Financial Structure on Stock Price Fluctuations of Listed Companies in Tehran Stock Exchange, Journal of Accounting Research, No. 21.

Ansari, A, \& Safari, S, (2012). Investigating the Impact of Operating Leverage and Financial Leverage on Capital Cost o, Journal of Financial Accounting Research, No. 3.

Atkeson-december (2005). A dynamic theory of optimal capital structure \& executive compensation-Andrew

Chaibi, A. and Gomes, M. (2013). Volatility Spillovers between Oil Prices and Stock Returns: A Focus on Frontier Markets, Working Paper", IPAG Business School, 34: 1-17

Dang, V.A. \& Garrett, I. (2015). On Corporate Capital Structure Adjustments. Finance Research Letters, 14, 56-63.

Dulo, Maryam, Rezaeian, Alireza, (2016). Deviation from the target leverage, cash flow imbalance and capital structure adjustment, Journal of Financial Research, Faculty of Financial Management, University of Tehran, Vol. 18, No. 2, pp. 287-306.

Farnklin J. S. \& K. Muthsamy, (2011). Impact Of Leverage on Firminvestment Decision”, International Journal of Scientific \& Engineering Research, Vol.: 2, Issue 4

Hong, H., Bian, Z., \& Chen, N. (2019). Leverage effect on stochastic volatility for option pricing in Hong Kong: A simulation and empirical study. The North American Journal of Economics and Finance, 100925.

Hsu, L. \& Jang, S. (2008a). The determinants of the hospitality industry's unsystematic risk: a comparison between hotel and restaurant firms", International Journal of Hospitality and Tourism Administration, Vol. 9, No.2, pp. 105-127. 
Ippolito.F, Steri R, \& Tebaldi C. (2017). Levered Returns and Capital Structure Imbalances. . Journal of Empirical Finance, 25(4), 489-502.

Koh, Y., Lee, S. \& Boo, S.Y. (2009). Does franchising help restaurant firmvalue?”, International Journal of Hospitality Management, Vol. 28,No. 2, pp. 289-296.

Lee, S. \& Xiao, Q. (2011). An examination of the curvilinear relationship between capital intensity and firm performance for publicly traded US hotels and restaurants", International Journal of Contemporary Hospitality Management, Vol. 23, No. 6, pp. 862880 .

Nikoomaram, H, Rahnama Roodposhti F, \& Heibati, F (2009). Fundamentals of Financial Management, Volume Two, Terme Publications.

Oino, Isaiah, \& Ben Ukaegbu. (2015). The impact of profitability on capital structure and speed of adjustment: An empirical examination of selected firms in Nigerian Stock Exchange." Research in International Business and Finance 35 (2015): 111-121.

Ozdagli, A. K (2012), Financial leverage, corporate investment, and stock returns, Review of Financial Studies, 4, 1033-1069.

Park, S.Y. \& Lee, S. (2009). Financial rewards for social responsibility: a mixed picture for restaurant companies", Cornell Hospitality Quarterly, Vol. 50, No.2, pp. 168-179.

Saati Ghare Musa, E, Shakiranov, H, \& Mirmohammadi, M (2017). Investigating the Relationship between Financial Leverage and Market Size and Stock Returns of Companies Listed in Tehran Stock Exchange, Journal of Modern Research Approaches in Management and Accounting, No. 2, pp. 1-15.

Tsai, H. \& Gu, Z. (2007). Institutional ownership and firm performance: empirical evidence from U.S.-based publicly traded restaurant firms", Journal of Hospitality \& Tourism Research, Vol. 31, No. 1, pp. 19-38.

Xu, V. A. (2012). Asymmetric Capital Structure Adjustments: New Evidence from Dynamic Panel Threshold Models. Journal of Empirical Finance, 19(4), 465-482. 